\title{
Market Reaction to the Issuance of Capital Instruments by Brazilian Banks
}

\author{
André Ricardo Moncaio Zanon ${ }^{1}$ \\ zanonandre@gmail.com | (1)0000-0002-7525-1862 \\ José Alves Dantas ${ }^{1}$ \\ josealvesdantas@unb.br | (D)0000-0002-0577-7340
}

\begin{abstract}
Banks are allowed to employ debt instruments in order to meet the minimum requirements of capital, as long as they comply with the subordination agreements as determined by the Basel Accords. This paper takes account of the effective powers of these instruments, viewed from the standpoint of the investors, and seeks to assess their impact on the return on investments in the shares of the issuing banks within Brazil's capital markets. The article is, to a large extent, based on the research findings of Ammann et al (2017). The results of the empirical tests - which were conducted by means of event studies that involved issuing 30 instruments during the period 12/2008 - 09/2017 - suggest that the issuances or announcements of these instruments had an adverse effect on the stock market value of the issuing banks. In addition, evidence was obtained that the market is unable to forecast the effects of these instruments before they take place. This paper seeks to contribute to the current literature on prudential regulations for banking and it hopes to assist banks in making decisions about capitalization.
\end{abstract}

\section{KEYWORDS}

Capital Instrument, Basel Accords, Capital, Banks, Stock Market

${ }^{1}$ Universidade de Brasília, Brasília, DF, Brasil

Received: $03 / 27 / 2018$

Revised: 09/11/2018.

Accepted: 03/21/2019.

Published Online: 10/23/2019.

DOI: http://dx.doi.org/10.15728/bbr.2020.17.1.1 
As stipulated by the regulations, banks must meet the minimum capital requirements for confronting risks to their operations, by being able to issue asset-backed instruments that comply with the required conditions of Basel III [OR The Basel Committee on Banking Supervision] the so-called instruments of debt eligible as capital (IDEC). They are the means of raising funds and are subject to other obligations, in the case of the winding up of a credit institution, and must meet the determined requirements outlined in the Basel Accords. These seek to ensure that the conditions for the dependence of these instruments are effective and that the issuing bank has an appropriate capital adequacy ratio.

After the first Basel Accord was enforced by law in 1988, banks began to issue IDEC, with the aim of strengthening their regulatory capital and preventing governments from making use of public funds to help them out during an economic crisis. These instruments acted as an alternative to capital itself and replaced the need for the shareholders themselves to hold more capital in the bank. In addition, it allowed the funds of third parties to be taken into account, provided that they met certain conditions, notably compliance with a subordination agreement.

The aim of this study is to determine the reaction of the market to the issuing of IDEC by Brazilian banks. These are described in the international world as contingent convertible capital instruments (CoCos), in light of the possibility of their being converted to shares or alternatively, made defunct (write-down) in accordance with the rules of Basel III (BCBS, 2011), owing to both the costs incurred and benefits derived from these instruments, as viewed from the standpoint of the shareholders.

Theoretically, the IDEC increases the solidity of the banks by strengthening their regulatory capital and enabling them to absorb losses, as well as providing the issuing banks with leverage and allowing them to carry out further financial transactions. As there are subordination clauses in these instruments - including those allowing debt extinguishment or convertibility to shares - it is natural that the cost of raising funds from them might be greater than other means of non-subordinated fund-raising, although capitalization through IDEC may be preferable to capitalization through capital itself which, theoretically is more expensive.

This perspective can at first find a home in the trade-off theory of capital structure which supports the idea that debt-based fund-raising provides the entity with a fiscal advantage through deducting expenses of interest rates based on a calculation of taxes, which makes the cost of third-party capital less than the cost of capital itself (Myers, 1984; Myers \& Majluf, 1984; Gallina, Ferreira, $\&$ Araújo, 2015). Nonetheless, this advantage of exchanging capital itself for debts would be beneficial up to a certain point because it increases the risks of the most indebted institutions, including that of insolvency, and thus leads to an increase in the cost of fund-raising.

However, given the characteristics of financial institutions which have a powerful regulatory impact on the market in their dealings, and where an awareness of risk on the part of the market players is extremely important for the operating conditions of the system, it is natural to assume that the issuing of IDEC only takes place when the entity is unable to raise funds internally and what prevails is a theory of the pecking order. This is characterized by an order of preference between the funds drawn on by the institutions: first, the funds raised internally through the inclusion of reserves and profits; second the issuing of new debts and finally the releasing of new shares (Myers, 1984; Myers \& Majluf, 1984).

The distinctive feature of the requirements of regulatory capital that are designed to ensure an appearance of solidity and stability for the banking system have led to questions being raised by authors such as Admati, Demarzo, Hellwig and Pfleiderer (2013), who argue that the IDEC is not a good substitute for shares and, moreover, can incur fund-raising costs that are higher 
than the issuing of shares. The explanation for this, according to Admati et al. (2013), is that the size of the losses that the IDEC can absorb will be very small or will lead to the investors of these instruments being unduly exposed, particularly as they will often be investors with a fixed income who are unprepared for sudden and large losses, such as the shareholders are accustomed to sustaining.

In view of this duality with regard to the effects of the issuing of IDEC - strengthening capital and allowing the leveraging of business without the need to provide one's own capital, while increasing the cost of fund-raising and an awareness of risk with regard to the issuers - there have been a number of studies in the international sphere such as those of Schmidt and Azarmi (2015), Avdjiev, Bolton, Jiang, Kartasheva and Bogdanova (2015), Ammann, Blickle and Ehmann (2017), and Liao, Mehdian and Rezvanian (2017), that have sought to examine what effect these issues have had on the value of the issuing banks. These studies are based on empirical evidence that is not entirely reliable since there are positive, negative and neutral effects on the issuing banks, a matter that is explored more fully in Section 2.1.

In the case of Brazil, which still lacks any study in this area, it is expected that there will be an even greater stress on risk awareness, particularly when account is taken of the fact that most of the issues of IDEC by Brazilian banks take place in the international market, which results in aggregating the value of the risk in the country to the risk of the institution and influencing the pricing method of these instruments.

In light of the predictions of the pecking order theory, it was expected that, in this study, the issuing of IDEC would be regarded by shareholders as entailing a greater awareness of risk with regard to the issuer. Moreover, there would be an involvement of the profit margins and flows of dividends, bearing in mind the impact on the cost of raising funds from the third-party capital, which would explain why there was a negative impact on the return on investment in the shares of these banks. This was determined through a study of events in which the effects of 30 debt security issues carried out in the period 02/2008 to 09/2017 were examined in the return on investment in the shares of the issuing banks.

The results of the empirical tests confirmed this expectation and provided evidence that the issuing of IDEC generally has a negative impact on the shares value of the issuing banks in the Brazilian market. The findings of the research suggest that, generally speaking, the market understands that the benefits derived from the issuing of IDEC do not outweigh its costs and risks - at least in the view of the investor.

The purpose of this study is to contribute to the growing literature on the subject, particularly considering that no theoretical framework has yet been established, and that the collection of empirical evidence is still in its early stages. To some extent, this can be explained by recent amendments to the rules of the Basel Accord in regard to the features required to ensure the IDEC is able to meet the requirements of regulatory capital - and show results that are not wholly compatible with each other.

For this reason, the results obtained in the Brazilian market can assist in a broader mapping of the effects of the issuing of these debt instruments. This is particularly the case if some features of this market are taken note of, such as the importance of the Brazilian economy in the regional sphere, a prevailing climate of high interest rates, the resilience of the system as borne out by the global financial crisis of 2008, as well as internal economic crises, the greater concentration of the market, and the importance of the banks under State control, among other factors.

Apart from this introductory section, which contextualizes the subject and defines its objectives, this study investigates the following: the theoretical principles and review of the literature about the effects of the issuing of IDEC in the return on the investment of the shares of the issuing 
BBR

17

4

banks (Section 2); the definition of the procedure for carrying out the empirical tests (Section 3 ); the assessment and analysis of the results of the studies of key events (Section 4); and the final considerations of the study, which includes the collation of the empirical evidence obtained and the theoretical framework (Section 5).

\section{THE THEORETICAL FRAMEWORK}

In the Basel Accords I and II, the IDEC were classified, according to their characteristics, as Hybrid Capital Instruments, or subordinated debt. In Brazil, there was an opportunity to employ these instruments for meeting the required conditions of capital on the basis of Resolution 2.543, enacted on August 2013, of the National Monetary Council (or Conselho Monetário Nacional$\mathrm{CMN}$ ), which is in favor of the Basel I Accord. Until then, the alterations of national standards had always followed the deliberations of Basel.

The IHCD are the IDEC that combine aspects of capital and debt. In accordance with the Basel I regulations, the features of IHCD may differ between different countries but they must satisfy the following capital requirements: subordination to other debts of the issuer; payment entirely in cash, a lack of guarantees, impossibility of redemption proceedings by the creditor or without the previous consent of the supervisory authority and the possibility of deferring their obligations as laid down in the instruments by the issuer (Basel Committee on Banking Supervision - BCBS, 1988).

The instruments that had the same character as the IHCD, but did not meet all the requirements, were described as subordinate debts i.e. instruments that were not guaranteed and had a minimum maturity period of five years. In contrast with IHCD, the funds represented by these instruments were not usually available to absorb the losses of a bank that continued to operate and this was why they were limited to a maximum of $50 \%$ of Tier 1 Capital of the issuing bank (BCBS, 1988).

Following the implementation of Basel III, the IDEC ceased to be designated as IHCD or subordinate debt, and a new term was employed ("instruments that meet the criteria for inclusion in capital" to cover types of instruments issued by financial institutions which can be used to form its Tier 1 or Tier 2 Capital.

The IDECs that adhere to the required conditions of Basel III have features that were already foreseen in the IHCD, such as subordination to other liabilities of issuers, and have new requirements. Among these, attention should be paid to the need for predicting their writedown or conversion into shares from the balance of debt represented by the instrument, should any mechanisms be triggered that are specified in the prudential regulations: the Common Equity Tier 1 Capital of the issuing institution remains below a) the adequate level of liquidity; b) the input of government funds to assist the issuing institution; c) an order decreed by a particular temporary management or $\mathrm{d}$ ) the intervention of the issuing institution; or the supervisory authority that determines the conversion or extinguishment of the IDEC (BCBS, 2011).

In light of these features regarding the convertibility into shares or extinguishment of debt, the IDECs issued, in compliance with the rules of Basel III, are generally designated contingent convertible capital instruments (CoCos). This means that a CoCo corresponds to an IDEC issued under the conditions laid down by Basel III, in which the convertibility/write-down clause is one of the requirements. This explains why studies that are confined to the IDECs issued under the conditions of Basel III are usually regarded in the literature as CoCos. One of the objectives pursued by the regulator is to ensure that these instruments can absorb potential losses from the issuer in unforeseen situations, thus preventing public funds being drawn on, or requiring the need for depositors to help out financial institutions in difficulty. In summary, the IDECs that are issued, and in compliance with Basel III, necessarily include a clause of subordination to 
other entity debt, and depending on contingent factors, can either be write-down or converted into shares.

In Brazil, among other standards that have been published to ensure the country is in compliance with Basel III, it is worth highlighting Resolutions 4.192 and 4.193, - both enacted on March 1st 2013, by the National Monetary Council (CMN) - which is responsible for calculating the regulatory capital of financial institutions, made up of Tiers 1 and 2. Tier 1 is itself divided between two tiers 1) Common Equity Tier 1 (the primary funding source of the bank) and 2) Additional Tier 1 Capital. In regulatory terms, the amount of capital that a bank can hold is defined by means of its risk-weighted assets (RWA). Thus, for example, their Regulatory Capital of a bank must be several times greater than the size of its assets and credit risk exposure, both in the market and for operational purposes.

Common Equity Tier 1 is primarily formed of a) shares (ordinary and preference, since they are non-redeemable and non-cumulative dividends), b) capital reserves and c) accumulated profits. Hence, this represents the area of greatest quality that is most suitable for absorbing losses since the regulatory adjustments and deductions are made from this sum, as stipulated by Resolution CMN 4.192/2013. Additional Tier 1 and Tier 2 Capital are formed by the IDEC (perpetual in the former case and with more than five years of maturity in the latter) and, before becoming regulatory Capital, must be approved by the Central Bank of Brazil.

\subsection{Studies on the Reaction of the Market to the Issuance of IDEC}

The determinations of the Basil Accords and their effects have been the object of considerable attention on the part of researchers and players in the market, because of the importance of their guidelines in ensuring the solidity and stability of the financial markets, as well as their wide scope - since they have been adopted by numerous countries in different continents. This is particularly the case in regards to the effects of issuing instruments to meet the requirements of capital, the object of this study, and have been found in some other studies in the international sphere, among which attention should be drawn to those of Schmidt and Azarmi (2015), Avdjiev et al. (2015), Ammann et al. (2017) and Liao et al. (2017). As all these studies were based on instruments with a convertibility clause, the IDECs that are designated CoCos.

Schmidt and Azarmi (2015), for example, analyzed the effects of an issuance of CoCos undertaken by Lloyds Bank in Britain in 2009, a pioneer among European countries. By employing a methodology involving a study of key events, the authors documented a reduction in the value of the market share of the bank after it announced its intention to issue CoCos and, at the same time recorded that there had been an increase in the spread of Credit Default Swaps (CDS). Thus, Schmidt and Azarmi (2015) concluded that the issuance of CoCos can have a negative effect on the creditworthiness and value of the banks.

Avdjiev et al. (2015) also carried out an empirical study on the market shares of CoCos issued by banks. The authors noted the effect of the issuance of CoCos on the spread of CDS and on the prices of the bank shares of Europe, Asia, Australia, and Latin America. The results revealed the negative and statistically significant impact on the spread of CDS, in a way that meant the issuing of CoCos would reduce the credit risk of the banks. It was argued that the costs of financing the banks depend on the features of the contracts that protect the issuance of CoCos and the characteristics of the banks, since the convertible instruments in the shares have a more negative impact on the CDS. In line with the forecasts based on the Theory of Corporate Finance, it was also found that the price reaction of the shares to the issuance of CoCos may not have a clear direction, since this can have either positive or negative effects, depending on the features of the issuance itself (in information leaflets), risk-taking,or the leveraging of the banks. Avdjiev et al. 
BBR

17

6

(2015) noticed that investors seemed to ignore the risks inherent in the CoCos, and were more concerned with the remuneration provided by these instruments.

The effects of issuing CoCos in Europe were also investigated by Ammann et al. (2017), who studied a group of 34 banks, in the period January 2009 - June 2014. By looking at key events, the authors examined the existence of abnormal returns in the price of shares and changes in the spread of CDS [Credit Default Swap], both before and after the dates when the issuance of IDEC was announced. They claimed that the announcement regarding the issuance of IDEC was correlated with positive abnormal returns on the shares and a reduction of the spread of CDS in the period immediately following the announcement. The authors explained these findings through a set of theories, including that which defines the least probability of a costly bankruptcy, which is based on the theory of the pecking order and the advantages of the fiscal cost of IDEC on shares.

Another similar study was carried out by Liao et al. (2017), which employed a study of key events to analyze the effects of 68 announcements of the issuance of CoCos, for 46 banks in 16 countries - China, Australia, India, Malaysia and 12 European countries - in the period 2010 - 2014. After estimating the Cumulative abnormal return - CAR) in the period of 15 days before and 15 days after the announcements of the issuance of CoCos, the authors found out that the banks usually experience negative abnormal returns in the immediate aftermath of the announcement.

However, in their analysis of data per country, Liao et al. (2017) discovered that there is not a uniform reaction by the investors to the announcement of the issuance of CoCos. In some markets, like Australia, India, Britain, and Switzerland, the investors reacted negatively during 15 day period following the announcement of the issuances, whereas in other countries such as Germany and Spain, they responded positively. In the view of Liao et al. (2017), these different reactions create opportunities for investors and the issuers adopted global diversification and trading strategies.

Hence, it was found that the results concerning the effects of the issuing of IDECs are not uniform since they obtained relations that were positive (Ammann et al., 2017), negative (Schmidt \& Azarmi, 2015; Liao et al., 2017) and neutral (Avdjiev et al., 2015) between the issuance of IDEC and the return on investment of the shares from the issuing institutions of these instruments. In regards to the countries where these issuances were undertaken, the results show that the issuance of IDECs by banks in countries like Britain, India, and Switzerland led to negative effects for the issuing institutions, whereas in the case of other European countries like Germany and Spain, a positive reaction was observed for the issuing of these financial instruments. The reasons for these differences in the results in terms of geographical locality, are not fully explained in the literature although attention should be drawn to the fact that positive reactions to the issuance of IDEC were only found in countries within the Euro zone.

Thus, the empirical evidence reveals a pattern of vagueness and ambiguity in the results given in the literature which underlines the importance of this study both with regard to this matter on which there is still no general consensus in the international literature and because it incorporates evidence of a market that has still not been explored in these research studies.

\subsection{Positive or Negative Factors regarding the Issuance of IDECs, From the Standpoint of THE Shareholders}

Alternative factors (both positive and negative) must be analyzed to understand the positive reactions to the IDEC market from the standpoint of the shareholders (investors), and of the issuers of these instruments with the purpose of capitalization. 
One negative factor linked to the issuance of IDECs by banks is, of course, the cost of raising funds from these instruments, compared with other kinds of funding (for example, CDBs, letters of credit,and savings), since thy have subordination clauses which determine that the value of these instruments can only be paid to creditors after the payment of other debts and loans of the issuing institutions in case of dissolution/discontinuity. In addition, in the case of $\mathrm{t}$ a IDEC issued in compliance with the rules of Basel III, it is possible that the debt represented by these instruments will be write-down or converted into shares, a fact that should further increase the cost of raising funds of this type of financial security. Evidence of this was obtained by Securato, Carrete and Securato Junior (2006), who studied the pricing policy for instruments by applying the binomial model to provide debt instruments and their components as well as to determine to what extent the subordination clauses reduce the nominal value of the corporate bonds.

From an opposite standpoint, Dutordoir, Lewis, Seward and Veld (2014) highlight the fact that convertible instruments can also be regarded as a mechanism for reducing the costs of an adverse form of selection that arises from the asymmetry of information between insiders and outsiders. In obtaining this understanding, the greater the uncertainty of the investor in regards to the risks of the issuer, the higher the rate of return required - a fact that can prevent the operation from being feasible for the issuer. The issuing of convertible instruments would mitigate this situation, given the fact that the option of conversion can lead to a fair pricing policy. In the particular case of the IDEC, however, it should be stressed that the conversion is not an "option" of the investor, but rather a condition imposed by the banking regulator, stemming from subordination clauses for other debts.

On the other hand, it can be expected - at least theoretically - that, on the basis of the trade-off and pecking order theories (Myers, 1984; Myers \& Majluf, 1984), that the cost of raising capital by means of IDECs should be less that the cost of issuing shares. Thus, as a means of meeting the minimum capital requirements in a less burdensome way, the institutions can choose to issue asset-backed debt instruments instead of shares, although Admati et al. (2013) think that the IDEC can incur an issuance cost that is higher than the capital itself.

Other factors should be taken into account apart from the cost of raising capital, when a financial institution decides to increase its regulatory capital by means of issuing new shares or instruments. Ashcraft (2008), for example, noted that, while the requirements of regulatory capital allow a bank to replace shares with subordinated debts, the creditors and investors regard the debt and liquid assets as imperfect substitutes. In his view, the proportion of debts and shares affects the role of the market in disciplining the behavior of the banks but only if the investors can impose real restrictions on them. In addition, the author argued that before implementing the Basel Accords, the greater proportion of debts in regards to shares made bank losses and insolvency less likely, when the investors had direct control over the issuing bank, and also when these debts included restrictive clauses. Moreover, after the Basel Accords, the replacement of shares with subordinated debts only increased the likelihood of bank losses and insolvency.

De Bandt, Camara, Maitre and Pessarossi (2017) noted that there is a prevailing view in the empirical literature that is in favor of capital having a positive effect on the performance of banks. In this area, panel data that was gathered by a French supervisor was employed and evidence obtained of this beneficial effect of capital; however, the study attempted to take a further step by distinguishing between regulatory and voluntary capital. In this way, the authors were able to show that through the existence of voluntary capital, the capital held by the banks independently of regulatory requirements, affects the banks in a positive way. In contrast, the effects of regulatory capital on the profitability of banks seems to be insignificant, which implies that the increase in capital requirements does not have an adverse effect on profitability in the banking sector in France. 
BBR

17

In line with this discovery, other studies noted that, depending on the type of IDEC issued, different results can be found. This is the case, for example, of Hilscher and Raviv (2014) who claimed that the convertible shares of the issuing banks of IDEC are less likely to fail to comply with their obligations, when compared with banks that issue non-convertible IDEC shares.

Another factor, that has been the subject of research and can have both positive and negative effects, is the impact of the issuance of IDECs on risk-taking by the financial institutions. Blum (2002) showed in his study that the issuing of subordinated debt only reduces the risk if the banks are in a position to be committed to sustaining a determined level of risk. However, if the banks are unable to make this commitment, the issuing of subordinate debt leads to an increase in risk. This is because owing to their limited responsibility, there is an incentive for them to increase their risk after the rate for the operation has been contracted, with a view to reducing the expected costs of the loan. The intelligent holders of these debts anticipate this behavior and thus require a greater ex-ante return on risk. In turn, higher interest rates discourage the banks from taking risks even more.

In contrast, Nguyen (2013) analyzed the disciplinary effect of issuing subordinated debt on the undesirable forms of risk-taking in the period 2002 - 2008. The author obtained evidence that the issuing of subordinated debt had an attenuating effect on the risk-taking of banks owing to the effects of discipline on the market. He also took note of the fact that banking regulations and the economic development of the country also mitigate the effects of the risk-taking of the banks.

A number of arguments in favor of and against the issuing of CoCos as a means of stabilizing the market were examined by Avdjiev et al. (2015). According to the authors, one key advantage arises when a bank that has issued CoCos, is building up losses as well as dangerously increasing its leverage. The conversion, or write-down, of its CoCos is a fast and effective means of reducing the leverage and leaving the bank in a more stable financial situation. At the same time, they noted that there are people who understand that CoCos are extremely complex and a deviation from the adequate capitalization of the banks.

Admati et al. (2013) argue that the bail out mechanism of the CoCos might not be very efficient since the size of the losses that these instruments can absorb will be much smaller or will overexpose their investors who will be mainly fixed income investors who are unprepared for sudden or large losses which the shareholders are accustomed to.

Greene (2016) notes that some academic studies have found that the issuance of IDECs can result in the following benefits (some of which are mutually exclusive): (i) improving the capacity of a bank to absorb greater losses while ensuring higher levels of capital in stressful situations; (ii) encouraging the holders of IDEC and/or shares and the bank managerial staff to be involved in the private monitoring of risks for fear of the conversion/write-down of the IDEC; (iii) increasing the banking liquidity at times of stress; (iv) preventing the banks from recovering from financial distress by making use of taxpayer funds; (v) limiting the stock dilution of the ROE [Return on Equity] with regard to the issuance of shares with the same volume. In addition, Greene (2016) highlights the fact that the issuing costs of IDECs are, theoretically, less exorbitant both for the banks and for the large-scale economy than the costs of issuing capital itself.

In contrast, other studies point out that: (i) the IDECs are a weak substitute for the greater requirements of capital; (ii) in a crisis situation, the conversion/write-down of these instruments would probably lead to the conversion/write-down of other IDECs, and thus spread out its effects; and (iii) the conversion/write-down of IDECs does not prevent the banks from continuing to make losses on poor investments since the issuing of new instruments only puts off the period of financial stress (Greene, 2016). 
Notwithstanding the arguments that highlight the positive and negative factors regarding the issuance of IDEC, as well as the results of empirical studies where results have been found that are not uniform in other markets with regard to the reaction of the market to the issuance of

IDECs, (as investigated in Section 2.1), this study is based on the following assumptions:

(i) the issuing of IDECs can be a sign of shortcomings in the capacity of the institution to make a profit from its own operations at a threshold that is sufficient to fulfill the requirements of regulatory capital, and this increases the awareness of risk regarding the entity in light of the theory of the pecking order (Schmidt \& Azarmi, 2015). A bank that is making significant and sustained profits would not need to issue IDECs to achieve regulatory capital, because the revenue reserve (or its incorporation) would be accounted for as Principal Capital.

(ii) although accepted for the purposes of fulfilling the requirements of regulatory capital, the IDEC cannot be an ideal substitute for capital itself, a fact which can also be interpreted as an increase in the risk awareness of the market (Ashcraft, 2008; Admati et al., 2013; Greene, 2016). This is because the IDEC may have maturity and be redeemed by the issuing bank in a way that does not show the same degree of continuity in its financial transactions.

(iii) the increase in risk awareness, combined with the existence of subordination clauses, tends to result in a rise in the cost of raising funds from these financial instruments (Securato et al., 2006).

(iv) the fact that the Brazilian banks made use of the international markets as the principal domain for the issuing of the IDEC, has resulted in the risk country itself being incorporated in the amount of remuneration covered by the investors, which takes shape in a further surcharge for the cost of the operation. It is natural that when raising funds in the international market, Brazilian banks have to pay a larger remuneration to the creditors than the banks in North America or European countries, simply because Brazil has a lower credit rating.

(v) this increase in the cost of raising funds can undermine the profit margins of the institution which is reflected in the flow of dividends for the shareholders and the expectation of future economic benefits for the current owners.

(vi) the banks which operate in the Brazilian market generally make large profits, largely due to the high degree of bank spread. Thus, as already made clear in previous items, the issuing of IDECs can be a signal of an institution's insufficient capacity to make a profit from its own operations, contrary to what is expected in the market.

In light of this combination of effects, the following hypothesis has been formulated so that it can be tested empirically:

$\boldsymbol{H}_{\boldsymbol{I}}$ : In Brazilian capital markets, there is a negative relation between the issuance of IDECs and the sharereturns of the issuing banks.

In underlining the fact that the perspectives of the shareholders are taken into account in developing the research hypothesis, the effects of the issuing of IDECs are taken note of in the return on investment in the shares and not the purchasers of these financial instruments.

\section{METHODOLOGY}

When testing the effects of the issuance of IDEC in the shares return of the issuing banks, and testing the research hypothesis, the "event study methodology" was used as set out by Mackinlay (1997), followed by Schmidt and Azarmi (2015), Avdjiev et al. (2015), Ammann et al. (2017) 
BBR

17

10

and Liao et al. (2017). This method measures the abnormal return determined in the price of shares caused by the occurrence of a particular event which, in this study, is the issuing of IDEC.

As Brito, Batistella and Famá (2005) point out, the abnormal return corresponds to the part of the altered price of the return on shares caused by factors responding to variations in the market, which are calculated by the difference between the returns that are effectively confirmed and expected, if the event not have occurred. Thus, the abnormal return is calculated by the equation 1 .

$$
A R_{i, t}=R_{i, t}-E\left(R_{i, t} \mid X\right)
$$

In which: $A R_{i, t}$ is the abnormal return of asset $i$ on the date $t ; R_{i, t}$ is the effective return of asset $i$ on the date $t$, calculated in accordance with the equation $2 ; E\left(R_{i t} \mid X\right)$ is the expected return of asset $i$ on the date $t$, given $X$, measured through the model (equation 3 ); $X_{t}$ is the return on the market portfolio.

The calculation of the abnormal return depends on two factors: the effective return and the return expected by the asset in question. The effective return of the shares will be calculated by the capitalization method with continuous compounding which ensures greater robustness in the results when compared with the capitalization method involving discrete compounding, as is pointed out by Brooks (2002) and Soares, Rostagno and Soares (2002), and as expressed in the equation 2 .

$$
R_{i, t}=\ln \left(\frac{p_{i, t}}{p_{i, t-1}}\right)=\ln p_{i, t}-\ln p_{i, t-1}
$$

In which: $R_{i, t}$ is the effective return of asset $i$, in the period $t, p_{i, t}$ is the price of asset $i$, in the period $t ; p_{i, t-1}$ is the prce of asset $i$, in the period $t-1$.

The expected return of the asset is calculated on the basis of the model of the market (equation 3 ), which relates the return of the assets to the return of the market portfolio as a whole.

$$
R_{i, t}=\alpha_{i}+\beta_{i} R_{m, t}+\varepsilon_{i t}
$$

in which: $R_{i, t}$ is the return of asset $i$ on the date $t ; R_{m t}$ is the return of the market portfolio, on the date $t ; \varepsilon_{i t}$ is the error term in a regresson model, based on the assumption of the normality of the residues, or rather, $\sim \mathrm{N}(0, \sigma 2)$.

In this study, as well as in that of Brito et al. (2005), the Sao Paulo Stock Exchange Index (Ibovespa) will be used to represent the market portfolio.

\subsection{Identifying the Event Date}

When calculating the abnormal return, a key feature that must be noted is the determination of the event date which is not based on a simple criterion in this kind of work, since before the issuing of the IDEC, there can be communication through intent marketing for issuing these financial instruments which can produce some effect. In addition, the instruments can be regarded as eligible for capital after being authorized by the regulatory body of the financial institutions.

With respects to this, Avdjiev et al. (2015) regarded the issuing date of the IDEC as the event date, although they noted that, in the case of the issuance of CoCos, in contrast with the study of typical events, when all the key information has been announced to all the participants in the market at a clearly defined point, the "event date" is not well defined and it is also not obvious what is the ideal size of the event window to assess the total impact of the issuing of a CoCo.

In view of the difficulty that has been pointed out in determining the event date, as well as the dates considered in other studies, this study will carry out tests that make use of two event dates; 
the date for issuing the debt instrument, (corresponding to the date in which the trading of the the announcement of the issuance of IDECs was concluded); and the date of the announcement of the issuance, (defined as the time in which the disclosure was made to the market by the issuing bank, of the future issuance of the instrument), through the publication of a "key fact" or a "communication with the market".

The date of the announcement will correspond to the issuance date when the announcement of the issuance occurs after the issuance date of the instrument or the issuing instrument was not disclosed by means of a "key fact" or a "communication with the market".

\subsection{Definition of the Event Window}

Another key factor for estimating the abnormal return is determining the event window, defined in regards to the event date and the addition of a period both after and prior to this date.

In this study, the international studies on IDECs, in particular those of Schmidt and Azarmi (2015), Ammann et al. (2017) and Liao et al. (2017) are taken as parameters and tests which will be carried out with four event windows, while only employing the useful days and using the event date as a benchmark: twenty days before and twenty days afterwards $(-20 ;+20)$, resulting in a window of 40 days; fifteen days before and fifteen days afterwards $(-15 ;+15)$ - a window of 30 days; ten days before and ten days afterwards $(-10 ;+20)$ - a window of 30 days; and five days before and fifteen days after $(-5 ;+15)$ the event date - a window of a 20 days. The idea is to explore the different dimensions of windows (longer and shorter), as well as the symmetrical and asymmetrical temporal amplitudes with regard to the event date.

Thus, in light of the different ways of determining the event date (the issuing date or the date when the issuance was announced) with the different amplitudes for the windows of the event, eight combinations of windows have been carried out.

\subsection{Definition of the Estimation Window}

Once the date and event window have been defined, the following stage involved specifying the estimation window, which is the period of control prior to the period of the event. The returns confirmed in the estimation window are made use of to calculate the parameters of the expected return of the model (equation 3).

According to Ammann et al. (2017), in this study, the estimation window will be formed over a period of a 100 useful days before the event windows. Hence, the overlapping of the estimation and event windows will be avoided in a way that is recommended by Mackinlay (1997).

\subsection{Calculation of Cumulative Abnormal Returns}

When conducting a global analysis of the effect of the event on the return of investment on shares, the abnormal returns are accumulated between the first and last day of the event window, forming the Cumulative Abnormal Return (CAR), which is expressed by:

$$
\operatorname{CAR}_{i}\left(T_{1}, T_{2}\right)=\sum_{T_{2}}^{T_{1}} A R_{i, T}
$$

in which: $C A R_{i}$ is the abnormal return accumulatd from asset $i ; T_{1}$ is the first day of the event window; $T_{2}$ is the last day of the event window.

In this study, a comparative analysis will be conducted of the $C A R$ before and after the event date, in the tests concerned with the windows that have the same periods before and after the 
BBR

17

12

event date, $(-20 ;+20)$ e $(-15 ;+15)$, like Liao et al. (2017). In this setting, the argument is that the market can only identify the event date of the occurrence (through an announcement or issuance, depending on the case). Thus, a comparison is made between the abnormal returns of symmetrical returns immediately before or after the event date.

In turn, regarding the tests related to windows that have fewer periods before the event date, $(-10 ;+20)$ and $(-5 ;+15)$, the $C A R$ determined in the entire window will be analyzed, as in the case of Ammann et al. (2017). In this scenario, the assumption is that, before the event date - the announcement or issuance, depending on the case - the market knows about the event and can anticipate its effects. In this way, a single window is used and the abnormal return is identified with regard to the estimation window.

In short, the combination of the event day, the event window and assessment criteria of abnormal returns results in eight kinds of tests, as shown in Chart 1.

Chart 1

Tests according to event window and event day

\begin{tabular}{lcc}
\hline Event Date & Event Window & Assessment Criteria of Abnormal Returns \\
\hline \multirow{2}{*}{ IDEC issuance date } & $-20 ;+20$ & Window pre event \\
& $-15 ;+15$ & X \\
& $-10 ;+20$ & Windon post event \\
& $-5 ;+15$ & Wingle window \\
IDEC announcente date & $-20 ;+20$ & Windon post event \\
& $-15 ;+15$ & Single window \\
\hline
\end{tabular}

Source: authors.

The purpose is for this combination of tests a) to ensure a greater robustness in the results of the study, b) check that the evidence is consistent when examining the different approaches for defining the event date, the specific features of the event window and making an assessment of abnormal returns.

\subsection{Selection of the Sample and Source of Data}

When carrying out the empirical tests, a sample is compiled that is formed of events concerning issuance or the announcement of the issuing of IDECs, on the part of Brazilian banks with open capital between March 2008, which was the validity period of Resolution CMN 3.444, of 28th February, which implemented the rules of Basel II, and was subsequently revoked by Resolution CMN 4.192/2013, which instituted the criteria of Basel III, and September 2017.

The information about the issuances and announcements of the issuing of IDECs was obtained from the Securities and Exchange Commission of Brazilian systems, by means of which key facts were accessed together with communications to the market of the banks being researched. However, since not all the issuances were disclosed to the outside public by means of key facts or communication with the market, information was also obtained about the issuances of IDEC in news broadcast over the specialized media. 
Forming the sample of events involved taking account of the issuances of IDEC that took place when the shares of the issuing bank were being traded during the event and estimation windows in at least $75 \%$ of the days of the period.

The sample comprises 30 events, which allow 45 observations to be made, because some of the banks investigated had more than one type of shares traded in the stock exchange and hence allowed some events to have an influence on more than one asset from the instrument of the issuing bank.

When statistical tests were conducted, the date of the announcement corresponded to the date of the issuing of the instrument in 17 of the 45 observations, because in these cases the announcement of the issuance took place later than the issuing date of the instrument or else the issuing of the instrument was not disclosed by means of the "key fact" or "communication to the market".

It should be stressed that only one bank had issuances of debt instruments that occurred on the same day, which thus meant that the drawing up of an eligible contract for Tier 2 Capital would need to be analyzed together with an eligible contract for the Additional Tier 1 Capital, as if it was only an event.

\section{ANALYSIS OF THE RESULTS}

Before carrying out the empirical tests, the 30 issuances of IDECs examined in this study must be characterized. Table 1 shows the characterization effected by the issuance (with regard to amount and value), as well as the distribution for each type of bank, in terms of capital controls and the currency usage. The values are shown in US dollars and take account of the following: the need to ensure comparability throughout the period; and the fact that almost all the issuances have taken place in US dollars.

Table 1

IDEC issuance by listed brazilian bank, from february/2008 to september/2017 - USD millions

\begin{tabular}{|c|c|c|c|c|c|c|c|}
\hline \multirow{2}{*}{ Year } & \multirow{2}{*}{ Issuances number } & \multicolumn{2}{|c|}{ Type of bank } & \multicolumn{2}{|c|}{ Type of currency } & \multicolumn{2}{|c|}{ Total } \\
\hline & & Public & Private & US dollar & Reais & Value & Perc. \\
\hline 2008 & 0 & - & - & - & - & - & $0.0 \%$ \\
\hline 2009 & 2 & $1,500.00$ & 750.00 & $2,250.00$ & - & $2,250.00$ & $6.3 \%$ \\
\hline 2010 & 7 & 660.00 & $4,025.00$ & $4,685.00$ & - & $4,685.00$ & $13.1 \%$ \\
\hline 2011 & 4 & $1,500.00$ & $1,250.00$ & $2,750.00$ & - & $2,750.00$ & $7.7 \%$ \\
\hline 2012 & 12 & $11,375.00$ & $6,245.00$ & $17,620.00$ & - & $17,620.00$ & $49.1 \%$ \\
\hline 2013 & 1 & $1,950.00$ & - & $1,950.00$ & - & $1,950.00$ & $5.4 \%$ \\
\hline 2014 & 3 & $2,877.51$ & $2,495.43$ & $4,995.43$ & 377.51 & $5,372.93$ & $15.0 \%$ \\
\hline 2015 & 1 & - & $1,261.61$ & - & $1,261.61$ & $1,261.61$ & $3.5 \%$ \\
\hline 2016 & 0 & - & - & - & - & - & $0.0 \%$ \\
\hline 2017 & 0 & - & - & - & - & - & $0.0 \%$ \\
\hline Total & 30 & $19,862.51$ & $16,027.03$ & $34,250.43$ & $1,639.11$ & $35,889.54$ & $100.0 \%$ \\
\hline Perc. & & $55.3 \%$ & $44.7 \%$ & $95.4 \%$ & $4.6 \%$ & $100.0 \%$ & \\
\hline
\end{tabular}

Note: in case of issuences in Brazil, the amounts were converted to USD, considering the exchange rate prevailing at the date of the transaction. 
BBR

17

14

Practically $50 \%$ of around US\$ 36 billion issuances in IDECs, during the ten years researched, were concentrated in 2012, following the effects of the global financial crisis of 2008 and before the Brazilian economic and political crisis - which showed early warning signs in 2013 and became more acute at the beginning of 2015, with measures taken that resulted in the impeachment of the President of the Republic. This confirms the fact that the issuances of IDECs are closely linked to the need for banks to strengthen their capital base at times when there is an increase in their degree of exposure - through risk-weighted assets. This evolving pattern can be best shown in Figure 1, with the histogram of the issuances of IDEC in the period under study.

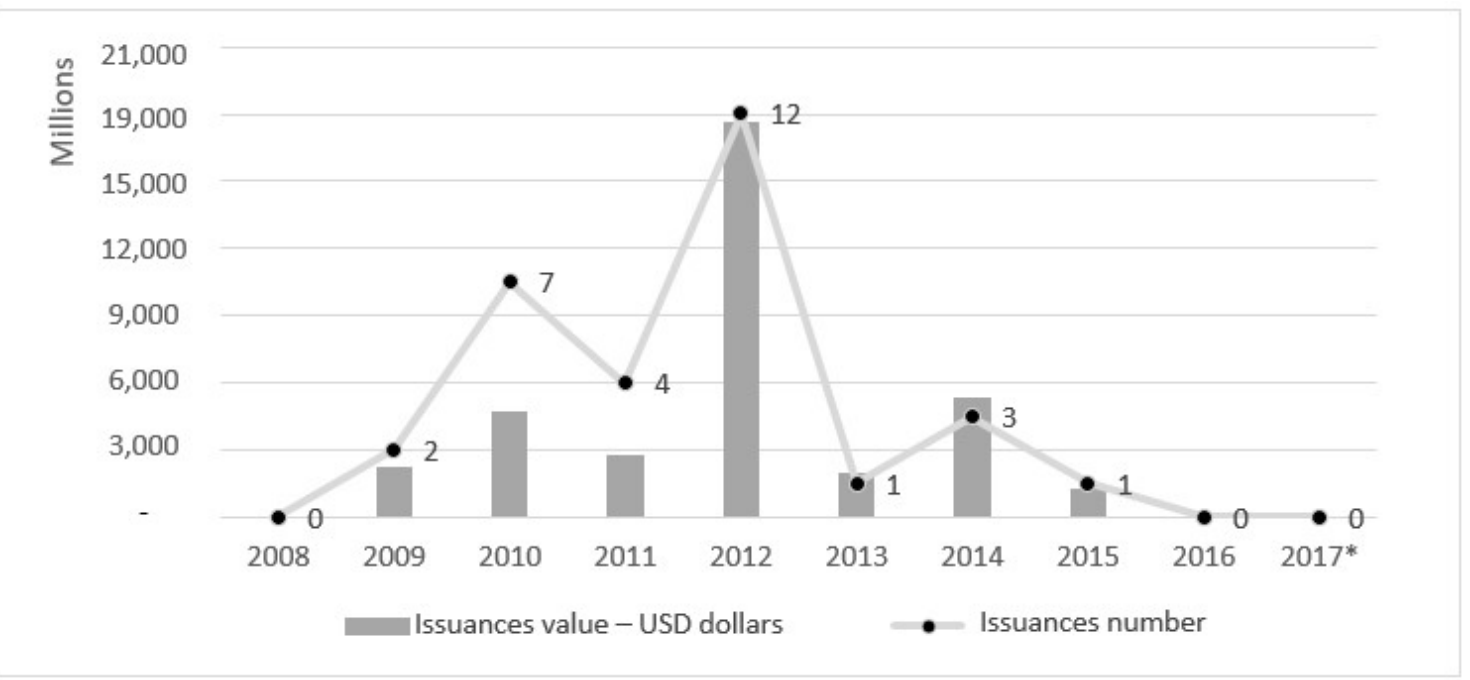

Figure 1. Histogram of IDEC issuances by listed Brazilian banks, from February/2008 to September/2017

With regard to the type of issuances, there is a degree of equilibrium between the issuances of IDEC by publicly-owned banks (55.3\%) and private banks (44.7\%), which reveals one must have had recourse to this type of instrument regardless of the type of capital controls and that there is indeed a need to bolster regulatory capital.

Finally, with regard to the currency of the issuance, there is clearly a preponderance of issuances in USD which represent more than $95 \%$ of the values of IDEC issued in the period. This concentration can be explained in terms of the following: a) the long-term features that can generally be found in these instruments required the support of a more stable currency; $b$ ) the fact that the bonds with the necessary features of IDEC, would be more common in the international market; c) despite the traditional climate of volatility, these kinds of instruments are not very common.

Moreover, it was found, in the national market, that the banks usually issue a instrument know as Letras Financeiras, with a subordination clause (LFS) for the purpose of forming capital. The LFS are also a type of IDEC, but were not employed in this study (except for raising a total sum of $\mathrm{R} \$ 5$ billion) because they usually have a lower value (there are LFS with a unitary value of $\mathrm{R} \$ 300.000,00)$ but their issuance usually is not disclosed by the institutions.

\subsection{Tests With CAR Before AND AFter the Event}

Following the methodological procedures defined in Section 3, according to Liao et al. (2017), the first stage of the empirical tests involves comparing the $C A R$, before and after the issuance date and the announcement date of the IDEC, including the significance tests (the basic 
principles of which are highlighted in Appendix I), for the $(-20 ;+20)$ and $(-15 ;+15)$ windows, as summarized in Table 2.

Table 2

CAR of the periods pre $x$ post event date - considering the dates of issuance and announcement

\begin{tabular}{|c|c|c|c|c|c|c|c|c|}
\hline & \multicolumn{4}{|c|}{ Issuance date } & \multicolumn{4}{|c|}{ Announcement date } \\
\hline & \multicolumn{2}{|c|}{ Window $-20+20$} & \multicolumn{2}{|c|}{ Window $-15+15$} & \multicolumn{2}{|c|}{ Window $-20+20$} & \multicolumn{2}{|c|}{ Window $-15+15$} \\
\hline & Pre & Post & Pre & Post & Pre & Post & Pre & Post \\
\hline Average & 0.0150 & -0.0277 & 0.0136 & -0.0210 & 0.0254 & -0.0221 & 0.0247 & -0.0113 \\
\hline Medium & 0.0181 & -0.0081 & 0.0120 & -0.0041 & 0.0120 & -0.0113 & 0.0181 & -0.0121 \\
\hline Maximum & 0.1819 & 0.0984 & 0.1575 & 0.1082 & 0.2347 & 0.1512 & 0.1693 & 0.1434 \\
\hline Minimum & -0.1458 & -0.3279 & -0.1203 & -0.2442 & -0.1458 & -0.3279 & -0.1177 & -0.2442 \\
\hline Standard deviation & 0.0726 & 0.0925 & 0.0679 & 0.0795 & 0.0758 & 0.0938 & 0.0644 & 0.0808 \\
\hline t stat & \multicolumn{2}{|c|}{2.7066} & \multicolumn{2}{|c|}{2.3413} & \multicolumn{2}{|c|}{3.4963} & \multicolumn{2}{|c|}{3.4762} \\
\hline P-value (t) & \multicolumn{2}{|c|}{$0.0048^{* * *}$} & \multicolumn{2}{|c|}{$0.0119^{* *}$} & \multicolumn{2}{|c|}{$0.0005^{* * *}$} & \multicolumn{2}{|c|}{$0.0006^{* * *}$} \\
\hline Z stat & 1.0174 & $-1.6494^{*}$ & 0.9438 & $-1.6560^{*}$ & $1,6984^{*}$ & $-1.6851^{*}$ & $1.8706^{*}$ & -1.2538 \\
\hline$Z$ post $-Z$ pre & \multicolumn{2}{|c|}{$-2.6668^{* * *}$} & \multicolumn{2}{|c|}{$-2.5998^{* * *}$} & \multicolumn{2}{|c|}{$-3.3835^{* * *}$} & \multicolumn{2}{|c|}{$-3.1244^{* * *}$} \\
\hline Observations number & \multicolumn{4}{|c|}{45} & \multicolumn{4}{|c|}{45} \\
\hline CAR significance level: & $\%(* * *) ; 5^{c}$ & $0\left({ }^{* *}\right) ; 10 \%$ & $(*)$. & & & & & \\
\hline
\end{tabular}

Source: authors.

As pointed out, on average the $C A R$ are positive before the event dates and negative afterwards for all the windows when the issuance or announcement are regarded as the event date. This implies that both the announcement and issuance of the IDEC were not welcomed by the market, because the $C A R$ were positive but began to be negative after the event dates.

This observation can be strengthened to check the difference between the averages of $C A R$ both after and prior to the event. If the issuance date is regarded as the event, this difference is $-0.0427,(-20 ;+20)$, and -0.0346 for the window, $(-15 ;+15)$ for the window, or in other words, after the issuance of the debt instruments, on average the abnormal returns on investment in the shares of the issuing banks fell from $4.27 \%$ to $3.46 \%$, when compared with the abnormal returns that were occurring before the issuing of these instruments. The differences between the averages of $C A R$ (afterwards and before) are similar when the event corresponds to the announcement date that is, -0.0475 , for the $(-20 ;+20)$ window, and -0.0360 , for the $(-15 ;+15)$ window.

According to the description in Appendix I, the results that are in accordance with the approach recommended by Fields and Mais (1991), were tested to determine if the results of this research are statistically significant, and led to a $Z$ statistic based on abnormal standardized returns. In addition, a t-test with two samples was conducted where the averages of the CAR were compared before and after the events.

As made clear in Table 2, all the results were statistically significant and included a combination of the definition of the event date and the size of the windows in two types of significance test. The difference between the $Z$ calculated by the $C A R$, before and afterwards, showed a confidence interval of $99 \%$ for all the windows, when the announcement and issuance were regarded as the event date. The t-Test showed that the difference between the averages of the CAR (before and afterwards) is statistically significant with a confidence interval of $95 \%$ for the $(-15 ;+15)$ window when the issuance was regarded as the event date and $99 \%$ for the other windows tested. 
BBR

17

16

Thus, these results reveal that the issuance or announcement of the issuing of IDEC had a negative impact on share return of the issuing banks, and confirms Hypothesis $\boldsymbol{H}_{\boldsymbol{1}}$ of this study. According to this, in the domain of Brazilian capital markets, there is a negative link between the issuance of IDEC and shares return of the issuing banks. It should be noted that the results were consistent in the four tests carried out - with the two dimensions of $(-20 ;+20)$ and $(-15 ;+15)$ windows and for the two event dates (issuance or issuing of the financial instrument).

\subsection{Tests of the Car in Single Windows}

Through the title of the contract notice of the different contexts, additional tests were carried out, following Ammann et al. (2017), and comparing the $C A R$ determined in the banking shares analyzed during the $(-10 ;+20)$ and $(-5 ;+15)$ single windows. These set out from the assumption that the information about issuance - and hence of its effects - materialized before the effective event date. Table 3 shows the descriptive statistics and the results of the significance tests that were applied.

Table 3

CAR of the periods pre $x$ post event date - considering the dates of issuance and announcement

\begin{tabular}{lcccc}
\hline & \multicolumn{2}{c}{ Issuance date } & \multicolumn{2}{c}{ Announcement date } \\
\hline & Window $-10+20$ & Window $-5+15$ & Window $-10+20$ & Window $-5+15$ \\
Average & -0.0289 & -0.0284 & -0.0009 & 0.0024 \\
Medium & -0.0427 & -0.0151 & -0.0214 & 0.0149 \\
Maximum & 0.1745 & 0.0989 & 0.2351 & 0.2183 \\
Minimum & -0.3290 & -0.2326 & -0.3290 & -0.2326 \\
Standard deviation & 0.1098 & 0.0821 & 0.1096 & 0.0952 \\
Z stat & -1.6135 & $-2.0663^{* *}$ & -0.2350 & -0.2557 \\
Observations number & 45 & & & 45 \\
CAR significance level: $1 \%(* * *) ; 5 \%(* *) ; 10 \%(*)$. & & \\
\hline
\end{tabular}

Source: authors.

If the date for the issuance of the instruments is regarded as the event date, it can be seen that the average of $C A R$ remains negative in the event window, although only the results of the window $(-5 ;+15)$ were statistically significant with a confidence interval of $95 \%$. In the cases when the event date corresponded to the date for announcing the issuing of instruments, the $Z$ statistics reveal that the results were not statistically significant for the two windows, $(-10 ;+20)$ and $(-5 ;+15)$, although they had negative signs. The average of CAR for both windows remained close to zero.

It should be noted that negative signs for the $\mathrm{Z}$ statistic were found for the four tests in Table 3 , which is compatible with the results obtained from the comparison of the prior and post event windows (Table 2), and consistent with Hypothesis $\boldsymbol{H}_{\boldsymbol{r}}$. However, it was only in the window test $(-5 ;+15)$, with the issuance as the event date, that a statistical significance emerged at a level of $5 \%$.

\subsection{Summary of the Relevance Tests of the $C A R$}

Following an examination of eight tests - a combination of two event dates (issuance and announcement), single windows (and pre $x$ post) and the different sizes of these windows - the results were obtained that are consolidated in Chart 2. 
Chart 2

Summary of test results - considering all events

\begin{tabular}{|c|c|c|c|c|c|c|}
\hline \multirow[b]{2}{*}{ Event date } & \multirow[b]{2}{*}{ Event window } & \multirow[b]{2}{*}{$\begin{array}{l}\text { CAR avaliation } \\
\text { criteria }\end{array}$} & \multirow[b]{2}{*}{ Signal finded } & \multicolumn{2}{|c|}{ Significance } & \multirow{2}{*}{$\begin{array}{l}\text { Hypothesis H1 } \\
\text { confirmation }\end{array}$} \\
\hline & & & & $\begin{array}{c}Z \text { (Fields e } \\
\text { Mais, 1991) }\end{array}$ & Teste-t & \\
\hline \multirow{4}{*}{ Issuance date } & $-20 ;+20$ & pre $\mathrm{x}$ post & negative & $\begin{array}{l}\text { significant } \\
\text { at } 1 \%\end{array}$ & $\begin{array}{l}\text { significantt } \\
\text { at } 1 \%\end{array}$ & not rejected \\
\hline & $-15 ;+15$ & pre $\mathrm{x}$ post & negative & $\begin{array}{l}\text { significant } \\
\text { at } 1 \%\end{array}$ & $\begin{array}{l}\text { significant } \\
\text { at } 5 \%\end{array}$ & not rejected \\
\hline & $-10 ;+20$ & single window & negative & $\begin{array}{c}\text { not } \\
\text { significant }\end{array}$ & not applicable & Rejected \\
\hline & $-5 ;+15$ & single window & negative & $\begin{array}{l}\text { significant } \\
\text { at } 5 \%\end{array}$ & not applicable & not rejected \\
\hline \multirow{4}{*}{$\begin{array}{c}\text { Announcement } \\
\text { date }\end{array}$} & $-20 ;+20$ & pre $\mathrm{x}$ post & negative & $\begin{array}{l}\text { significant } \\
\text { at } 1 \%\end{array}$ & $\begin{array}{l}\text { significant } \\
\text { at } 1 \%\end{array}$ & not rejected \\
\hline & $-15 ;+15$ & pre $\mathrm{x}$ post & negative & $\begin{array}{l}\text { significant } \\
\text { at } 1 \%\end{array}$ & $\begin{array}{l}\text { significant } \\
\text { at } 1 \%\end{array}$ & not rejected \\
\hline & $-10 ;+20$ & single window & negative & $\begin{array}{c}\text { not } \\
\text { significant }\end{array}$ & not applicable & rejected \\
\hline & $-5 ;+15$ & single window & negative & $\begin{array}{c}\text { not } \\
\text { significant }\end{array}$ & not applicable & rejected \\
\hline
\end{tabular}

Source: authors.

It was noted that negative signs for these abnormal returns were found in these eight tests, six of which were of statistical relevance. The set of these results are able to corroborate Hypothesis $\boldsymbol{H}_{\boldsymbol{1}}$ and suggest that, in the Brazilian capital markets, investors react adversely to the issuance of IDECs on the part of the banks. This reveals that the investors calculate that the benefits derived from the issuance of these instruments does not outweigh their costs, and the shares price of the issuers get lower.

Among the possible reasons that can explain this result, it can be speculated that the cost of raising funds from these instruments is generally higher than the non-subordinated debts. The issuance of these financial instruments can heighten risk awareness with regard to the issuing bank, and the creditors and investors might regard these debt instruments as shares and imperfect replacements, as argued by Admati et al. (2013). In light of this, it is worth remembering that banks do not need to issue these instruments to comply with the requirements of capital, since they can improve their levels of regulatory capital by reducing the risks and number of their operations or, for example, by increasing their social capital.

Furthermore, the market might assume that the issuance of IDECs would stimulate the banks to take on other risks, over and above what would be acceptable. With regard to this, Blum (2002) and Ashcraft (2008) demonstrated that the issuing of subordinated instruments can increase the risks taken on by banks, depending on the nature of the issuance of these financial instruments.

The set of results obtained from the statistically significant tests corroborate the findings of Schmidt and Azarmi (2015), who confirmed that the issuing of CoCos can have a negative effect on the value of a bank. They also support the study of Liao et al. (2017), who estimated cumulative abnormal returns $(C A R), 15$ days before and 15 days after the announcement of the issuance of CoCos, and concluded that banks usually experience abnormal negative returns in the aftermath of the announcement. 
BBR

17

18

At the same time, the results contradicted what was observed by Ammann et al. (2017), who found that the announcement of the issuance of $\mathrm{CoCos}$, in the domain of Europe, is correlated with returns of positive abnormal shares.

It is worth recording that, in the tests with single windows, $(-10 ;+20)$ and $(-5 ;+15)$, the $\boldsymbol{H}_{\boldsymbol{1}}$ hypothesis was only confirmed by one test. This involved the $(-5 ;+15)$ window which included the issuance as the event date and was rejected by three other tests because the results were not statistically significant for at least $10 \%$. On the other hand, all the tests with pre x post windows, $(-20 ;+20)$ and $(-15 ;+15)$ corroborate Hypothesis $\boldsymbol{H}_{\boldsymbol{1}}$ and were statistically significant in accordance with the $\mathrm{t}-$ Test and $Z$ statistic.

This difference in the statistical significance of the results for the types of windows suggests that the market is unable to anticipate the effects of the event before its occurrence, particularly when the announcement of the issuance corresponds to the event date. Thus, the market tends to price the effects of a new instrument of eligible debt capital after its issuance or the announcement of this issuance.

\subsection{Analysis of Sensitivity: Determinants of the Abnormal Return IN THE EVENT WINDOWS}

The calculation of the relevance of the CAR based on tests of averages (Statistics $t$ and $Z$ ) has an inherent limitation, which is that it does not allow the behavior of this return to be controlled, owing to the individual features of the banks and bonds and the state of the macroeconomic environment at the time of the issuances.

This means that a multivariate model of the determinants of CAR was estimated for the analysis of the sensitivity bond, in an attempt to determine if this abnormal return is influenced by the variables that represent the following: a) the value of the issuance of the IDEC with regard to the liquid assets of the bank $(\mathrm{Val})$; b) the level of prevailing economic activity at the time of the issuance, represented by the gross domestic product (GDP); c) the reference currency of the instruments issued; d) the condition of the bank's capital control and whether it will be public or private; and e) the issuance date of the IDEC.

The results of the estimates of the model, when regarded as a dependent variable, are listed in Table 4 with the CAR accumulated in the $(-20 ;+20),(-15 ;+15),(-10 ;+20)$ and $(-5 ;+15)$ windows, that include the issuance dates or announcement as a benchmark of the event.

The estimates demonstrate that there is a negative link between the CAR and the representativeness of the value of the issuance of IDECs with regard to the liquid assets, which provide evidence that the greater the value of the instrument, the worse the negative effect on the abnormal return. This data strengthens the evidence pointed out in the previous discussion, in so far as the issuance of these instruments has a negative impact on the bank shares. This becomes more important when there is an increase in the value involved. Thus, this supports the evidence by confirming the research hypothesis of $\boldsymbol{H}_{\boldsymbol{i}}$.

No significant statistics were found for the other variables made use of in the model that involved the $C A R$ of the windows under study. For example, no evidence was found of the abnormal return of the shares in the issuance windows of the IDEC, which were influenced by the prevailing degree of economic activity (GDP) during the quarter in which the event occurred. In the same way, no statistical significance was noted for the control variables Pre2012 and Pos2012 (the control between the periods pre and post 2012, which could be explained in terms of the high concentration of events in 2012, as outlined in the first part of Section 4). The set of results, with regard to the GDP variables, Pre2012 and Post2012, suggest that the time of the issuance of these debt instruments, including the prevailing macroeconomic situation, is not 
Table 4

Estimation model to identify determinants of the abnormal return of event windows

Model:

\begin{tabular}{|c|c|c|c|c|c|c|c|c|}
\hline \multicolumn{9}{|c|}{ CAR $_{i=;} \beta_{0}+\beta_{1} \mathrm{Val}_{i}+\beta_{2} G D P_{t}+\beta_{3}$ MEstr $_{i}+\beta_{4}$ Priv $_{i}+\beta_{5}$ Pre2012 $_{t}+\beta_{5} \operatorname{Pos}_{2012_{t}}+{ }_{\varepsilon}^{\mathrm{i}}$} \\
\hline \multirow{2}{*}{$\begin{array}{l}\text { Event } \\
\text { Window }\end{array}$} & \multicolumn{4}{|c|}{ Issuance Date } & \multicolumn{4}{|c|}{ Announcement Date } \\
\hline & $-20 ;+20$ & $-15 ;+15$ & $-10 ;+20$ & $-5 ;+15$ & $-20 ;+20$ & $-15 ;+15$ & $-10 ;+20$ & $-5 ;+15$ \\
\hline \multirow[t]{2}{*}{ Const } & $0.2502^{*}$ & 0.0888 & 0.1133 & 0.0464 & 0.1550 & 0.0665 & 0.0667 & 0.0368 \\
\hline & $(0.057)$ & $(0.417)$ & $(0.286)$ & $(0.554)$ & $(0.257)$ & $(0.577)$ & $(0.539)$ & $(0.698)$ \\
\hline \multirow[t]{2}{*}{$\mathrm{Val}_{\mathrm{i}}$} & $-0.5786^{* * *}$ & $-0.3023^{*}$ & $-0.3105^{* *}$ & $-0.2271^{* *}$ & $-0.4846^{* *}$ & -0.2592 & $-0.3151^{* *}$ & -0.1663 \\
\hline & $(0.003)$ & $(0.056)$ & $(0.043)$ & $(0.046)$ & $(0.015)$ & $(0.130)$ & $(0.045)$ & $(0.222)$ \\
\hline \multirow[t]{2}{*}{$\mathrm{PIB}_{\mathrm{t}}$} & 0.6747 & -0.4683 & -0.8434 & -0.7157 & 0.7914 & 0.2712 & -0.0737 & 0.0520 \\
\hline & $(0.529)$ & $(0.606)$ & $(0.339)$ & $(0.274)$ & $(0.484)$ & $(0.784)$ & $(0.935)$ & $(0.947)$ \\
\hline \multirow[t]{2}{*}{ MEstr $_{i}$} & -0.1941 & -0.0368 & -0.0669 & -0.0442 & -0.0968 & -0.0420 & -0.0212 & -0.0256 \\
\hline & $(0.123)$ & $(0.726)$ & $(0.511)$ & $(0.558)$ & $(0.460)$ & $(0.714)$ & $(0.839)$ & $(0.780)$ \\
\hline \multirow[t]{2}{*}{$\operatorname{Priv}_{i}$} & -0.0565 & -0.0271 & -0.0501 & -0.0157 & -0.0351 & 0.0005 & -0.0235 & 0.0098 \\
\hline & $(0.211)$ & $(0.477)$ & $(0.178)$ & $(0.565)$ & $(0.458)$ & $(0.990)$ & $(0.535)$ & $(0.767)$ \\
\hline \multirow[t]{2}{*}{ Pre2012 } & -0.0176 & -0.0025 & 0.0307 & 0.0345 & -0.0538 & -0.0286 & -0.0242 & -0.0370 \\
\hline & $(0.759)$ & $(0.959)$ & $(0.516)$ & $(0.327)$ & $(0.378)$ & $(0.593)$ & $(0.618)$ & $(0.388)$ \\
\hline \multirow[t]{2}{*}{$\operatorname{Pos} 2012_{t}$} & -0.0181 & -0.0007 & -0.0180 & 0.0276 & 0.0485 & 0.0842 & 0.0519 & 0.0627 \\
\hline & $(0.779)$ & $(0.989)$ & $(0.733)$ & $(0.483)$ & $(0.478)$ & $(0.164)$ & $(0.342)$ & $(0.194)$ \\
\hline N. Obs. & 45 & 45 & 45 & 45 & 45 & 45 & 45 & 45 \\
\hline $\mathrm{R}^{2}$ & 0.2500 & 0.1791 & 0.2426 & 0.2563 & 0.1944 & 0.1552 & 0.1983 & 0.1806 \\
\hline $\mathrm{R}^{2}$ Ajust & 0.1316 & 0.0495 & 0.1230 & 0.1389 & 0.0672 & 0.0218 & 0.0717 & 0.0512 \\
\hline F-stat & 2.1110 & 1.3820 & 2.0289 & 2.1830 & 1.5285 & 1.1632 & 1.5668 & 1.3956 \\
\hline
\end{tabular}

Where: $C A R_{i}$ is the abnormal return accumulated in the window of event $i$, calculated according to Section 3; Val ${ }_{i}$ correspond to the value of event $i$, determined by the ratio between the value of the IDEC and the entity's net equity; GDP $P_{t}$ correspond to the annualized variation of gross domestic product in quarter $t$ where event $i$ occurred; $M E s t r$ is a dummy variable, assuming 1 when the emission of event i occurred in foreign currency and 0 for issues in national currency; Priv is a dummy variable, assuming 1 when the issuing bank of event $i$ is privately controlled and 0 for when it is public; Pre2012 is a dummy variable, assuming 1 when event $i$ occurred in period $t$ prior to year 2012; Pos 2012 is a dummy variable, assuming 1 when event $i$ occurred in period $\mathrm{t}$ after year 2012.

Level of significance: ${ }^{* *} 1 \% ;{ }^{* *} 5 \% ;{ }^{*} 10 \%$. P-value in parentheses.

Source: authors.

a determining factor that can explain the abnormal return. With regard to the features of the instrument, the results of the tests, in regards to, the MEstr variable, reveal that the fact that the IDEC was issued in either national or foreign currency, does not explain the differences in the abnormal return of the window events examined. Finally, concerning the individual features of the banks, there were also no important differences noted between the private and public banks, in the abnormal return during the event windows.

It should be stressed that the restriction on the number of observations (45) represents a limitation with regard to the empirical results and makes it more difficult to obtain results that are more robust. For this reason, these estimates should be treated as preliminary evidence that needs to be explored in a wider context when there is an opportunity to increase the number of events Among the factors requiring further investigation, aspects of the capitalization policy of each entity should be highlighted - these are often influenced by unforeseen market restrictions, for example those resulting from the level of risk in non-banking entities, as documented by Denis and Mihov (2003). 


\section{FINAL CONSIDERATIONS}

The purpose of this study was to discover the reaction of the market to the issuance of IDECs by Brazilian banks, while taking into account the costs and benefits of these instruments from the standpoint of the shareholders, as made clear in the literature. The issuance of these instruments increases the levels of regulatory capital of the banks, and allows the leveraging of the operations of these institutions. However, this has a collateral effect by increasing the cost of raising funds, - the purchasers of these assets require a greater risk premium when acquiring these instruments because of the subordination clauses - and an awareness of the of the risk to investors of the capital markets with regard to the issuing entities.

The results of the empirical tests carried out by means of the study of events (which involved 30 issuances undertaken between 02/2008 and 09/2017, provide evidence that, in general terms, in the Brazilian market, the issuance of these instruments has a negative impact on the shares return of the issuing banks. This suggests that, in general terms, the market understands that the benefits derived from the issuance of IDECs does not outweigh its costs and risks, at least from the perspective of the investor. Moreover, evidence was found that the market is not able to anticipate the effects of the issuance or announcement of an instrument before its occurrence.

The banks do not need to issue IDECs to be supporters of the requirements of capital. Thus, the results of this study show that in seeking to improve their levels of capital, banks should, preferably, reduce their exposure and not issue IDEC, if they wish to maximize the return on their shares.

There are a number of limitations in this research of which the following should be noted: (i) the restriction in the number of free trading banks in Brazil; (ii) the limited number of events during the period of Basel II and III; (iii) the non-disclosure of relevant facts or communications to the market, related to all the IDEC that were analyzed; and (iv) the lack of a standard for the disclosure of the issuance of these instruments by the banks (some disclosed after the issuance). There is also a need to stress the limitations of the method itself. The studies of events can determine the impact of the return on investment in shares simply in terms of the uncertainty caused by the event itself, but only after returning to the average point, to the extent that the information is assimilated or even if new data is made available. The use of multiple windows, as carried out in this study, mitigates this risk but is unable to remove it altogether. The estimates of the determinant model of abnormal return also partly overcome these limitations, although the number of observations constrains the opportunity to test the effects of more specific factors.

Notwithstanding these limitations, this study is designed to contribute to the literature on the prudential regulations of banks, by addressing a feature of the issuance of IDECs that has not been investigated in the Brazilian domain. It also involves collaborating with international researchers in their studies on the subject, by allowing the features of the Brazilian market to be included as factors in the reaction of the market to the issuance of IDEC. Furthermore, the results of this research can assist banks in their decisions about capitalization, as far as they provide evidence about how the players in the market react to the issuing of debt instruments that are eligible for capital. 


\section{REFERENCES}

Admati, A. R., Demarzo, P. M., Hellwig, M. F., \& Pfleiderer, P. C. (2013). Fallacies, irrelevant facts, and myths in the discussion of capital regulation: Why bank equity is not socially expensive. Stanford University Graduate School of Business Research Paper, 13(7). Retrieved from https://ssrn.com/abstract=2349739

Ammann, M., Blickle, K., \& Ehmann, C. (2017). Announcement effects of contingent convertible securities: Evidence from the global banking industry. European Financial Management, 23(1), 127-152.

Ashcraft, A. B. (2008). Does the market discipline banks? New evidence from regulatory capital mix. Journal of Financial Intermediation, 17(4), 543-561.

Avdjiev, S., Bolton, P., Jiang, W., Kartasheva, A., \& Bogdanova, B. (2015). Coco bond issuance and bank funding costs. BIS and Columbia University Working Paper, (678). Retrieved from https://www.bis.org/publ/work678.pdf

Basel Committee on Banking Supervision (BCBS). (1988). International convergence of capital measurement and capital standards, Basileia. Retrieved from http://www.bis.org/publ/bcbs04a.htm

Basel Committee on Banking Supervision (BCBS). (2011). Basel III: A global regulatory framework for more resilient banks and banking systems, Basel. Retrieved from http://www.bis.org/publ/ bcbs189.htm

Blum, J. M. (2002). Subordinated debt, market discipline, and banks' risk-taking. Journal of Banking \& Finance, 26(7), 1427-1441.

Brito, G. A. S., Batistella, F. D., \& Famá, R. (2005). Fusões e aquisições no setor bancário: avaliação empírica do efeito sobre o valor das açóes [Mergers and acquisitions in the banking sector: an empirical assessment of the effect on the share values]. Revista de Administração RAUSP, 40(4), 353-360.

Brooks, Chris. (2002). Introductory Econometrics for Finance. Cambridge: Cambridge University Press.

De Bandt, O., Camara, B., Maitre, A., \& Pessarossi, P. (2017). Optimal capital, regulatory requirements and bank performance in times of crisis: Evidence from France. Journal of Financial Stability. In press. doi:10.1016/j.jfs.2017.03.002

Denis, D. J., \& Mihov, V. (2003). The choice among bank debt, non-bank private debt, and public debt: evidence from new corporate borrowings. Journal of Financial Economics, 70(1), 3-28.

Dutordoir, M., Lewis, C., Seward, J., \& Veld, C. (2014). What we do and do not know about convertible bond financing. Journal of Corporate Finance, 24, 3-20. doi:10.1016/j. jcorpfin.2013.10.009

Fields, L. P., \& Mais, E. L. (1991). The valuation effects of private placements of convertible debt. The Journal of Finance, 46(5), 1925-1932.

Gallina, A. S., Ferreira, J. C., \& Araújo, M. P. (2015). A influência das teorias da agência, tradeoff e pecking order no estudo da estrutura de capitais: uma revisão teórica. [The influence of the trade-off and pecking order theories on the study of the capital market ] I CINGEN - Conferência Internacional em Gestão de Negócios [International Conference on Business Management], UNIOESTE, Cascavel. Retrieved from http://cac-php.unioeste.br/eventos/ cingen/artigos_site/convertido/5_Contabilidade_Financeira_e_Financas/A_influencia_das_ teorias_da_agencia_trade_off_e_pecking_order_no_estudo_da 
BBR

17

22

Gonçalves, R. S., Barbosa, N. M., Barroso, C. R., \& Medeiros, O. R. (2015). Social disclosure e retornos anormais: um estudo de eventos em empresas brasileiras abertas no período de [Social disclosure and abnormal returns a study of events in open Brazilian companies] 2005 a 2012. Revista de Contabilidade e Organizaçóes, 9(24), 64-70.

Greene, R. W. (2016). Understanding CoCos: What operational concerns \& global trends mean for US policymakers. Harvard University, John F. Kennedy School of Government, M-RCBG Associate Working Paper, (62). Retrieved from https://ssrn.com/abstract=2907470

Hilscher, J., \& Raviv, A. (2014). Bank stability and market discipline: The effect of contingent capital on risk taking and default probability. Journal of Corporate Finance, 29, 542-560.

Liao, Q., Mehdian, S., \& Rezvanian, R. (2017). An examination of investors' reaction to the announcement of CoCo bonds issuance: A global outlook. Finance Research Letters, 22, 58-65.

Mackinlay, A. C. (1997). Event studies in economics and finance. Journal of Economic Literature, 35(1), 13-39.

Myers, S. C. (1984). The capital structure puzzle. Journal of Finance, 39(3), 575-92.

Myers, S. C., \& Majluf, N. S. (1984). Corporate Financing and Investment Decisions When Firms Have Information Investors Do Not Have. Journal of Financial Economics, (13), 187-222.

Nguyen, T. (2013). The disciplinary effect of subordinated debt on bank risk taking. Journal of Empirical Finance, 23, 117-141.

Schmidt, C. E., \& Azarmi, T. F. (2015). The impact of CoCo bonds on bank value and perceived default risk: insights and evidence from their pioneering use in Europe. Journal of Applied Business Research, 31(6), 2297-2306.

Securato, J. R., Carrete, L. S., \& Securato Junior, J. R. (2006). Precificação de títulos de dívida corporativa e seus componentes pelo modelo binomial [The pricing of corporate debt bonds and their components through the binomial model]. Revista de Administração - RAUSP, 41(1), 18-28.

Soares, R. O., Rostagno, L. M., \& Soares, K. T. C. (2002). Estudo de evento: o método e as formas de cálculo do retorno anormal [An event study: the method and means of calculating abnormal returns ]. In ANPAD, Anais do XXVI EnANPAD, Salvador. CD-ROM.

\section{ORIGEN OF THE ARTICLE}

This study is part of the dissertation carried out by the first author under the supervision of the second in the PostGraduate Accountancy Course at the University of Brasília (UnB) 
The approach recommended by Fields and Mais (1991) was employed to test the statistical significance, on the basis of standardized abnormal returns. The assumption is that the abnormal returns are multivariate in a standard and independent form. Thus, the $Z$ statistic was calculated to test the null hypothesis that the abnormal return was average or zero:

$$
Z=\frac{1}{\sqrt{n}} \sum_{i=1}^{N} \sum_{t=t_{1}}^{t_{2}} \frac{A R_{i t}}{S_{i T}}
$$

where: $n$ is the size of the sample; $A R_{i t}$ are the abnormal returns of institution i for the date $t$; and $S_{i T}$ indicates the standard deviation of the sum of the $A R_{i t}$ series during the period of the window event, as calculated by Fields and Mais (1991), in accordance with the equation (3.6).

$$
S_{i T}=\left\{\hat{\sigma}_{i}^{2}\left[T+\frac{T^{2}}{N}+\frac{T^{2}\left(R_{m T}-R_{m}\right)^{2}}{\sum_{t=1}^{N}\left(R_{m t}-R_{m}\right)^{2}}\right]\right\}^{\frac{1}{2}}
$$

where: $\hat{\sigma}_{i}^{2}$ is the mean square error of the regression of the model for the firm $j ; R_{m}$ is the average of the assigned index of the market during the period of estimation; $N$ is the number of returns in the period of estimation; $R_{m T}$ is the average of the index during the period $T$; the number of observations of the sample in the period of $t=T_{1}$ until $t=T_{2}$ is defined as $T$, where $T$ is $T_{2}-T_{1}+1$.

In this study, in the cases where the assessment criterion is the single window, the $\mathrm{Z}$ statistic is enough to compare the event window with the estimation window. In the cases in which the pre and post event date symmetrical windows are compared, the statistical $Z$ was analyzed relatively to the difference between the $\mathrm{Z}$ calculated for the $C A R$ post and pre event date.

In specific terms, an additional statistical significance test was conducted for the cases involving the comparison of the windows. Following Gonçalves, Barbosa, Barroso and Medeiros (2015), a parametric test of averages was conducted which includes a sample for the analysis of variance which has a normal distribution and uniform variance. In this study, the t-test was used: two paired samples for averages to determine if the difference between the averages of the $C A R$ post and pre event is statistically significant. 